\title{
Effects of Flaxseed and pH on the Emulsion Properties of Beef by Using a Model System
}

\author{
Şükrü Kurt* , Huriye Gözde Ceylan
}

Department of Food Engineering, Faculty of Engineering, University of Adlyaman, 02040 Adlyaman, Turkey

\begin{tabular}{|c|c|}
\hline ARTICLE INFO & A B S T R A C T \\
\hline Research Article & \multirow{6}{*}{$\begin{array}{l}\text { The effects of ground flaxseed }(0-0.5 \%) \text { and } \mathrm{pH}(3.88-8.12) \text { on the emulsion properties of } \\
\text { beef were studied using a model system. A central composite rotatable design was used to } \\
\text { determine the response surface. } \mathrm{pH} \text {, flaxseed and their interactions had significant effects } \\
\text { on the emulsion properties of beef. } \mathrm{pH} \text { and the interaction between } \mathrm{pH} \text { and flaxseed } \\
\text { increased emulsion capacity (EC). Flaxseed and } \mathrm{pH} \text { increased emulsion stability (ES) } \\
\text { until a critical point, which was reached at a flaxseed level of } 0.42 \% \text { and a pH of } 7.02 . \mathrm{pH} \\
\text { decreased emulsion density (ED) and increased emulsion activity (EA). Moreover, the } \\
\text { interaction between } \mathrm{pH} \text { and flaxseed on EA was found to be significant. } \mathrm{pH} \text { and flaxseed } \\
\text { increased emulsion viscosity (EV), and the increasing rate was higher in basic medium } \\
\text { than acidic. }\end{array}$} \\
\hline Received 01 May 2017 & \\
\hline Accepted 11 January 2018 & \\
\hline Keywords: & \\
\hline & \\
\hline nulsion & \\
\hline
\end{tabular}

Flaxseed

Model system

*Corresponding Author:

E-mail: sukrukurt@hotmail.com

DOI: https://doi.org/10.24925/turjaf.v6i1.78-83.1293

\section{Introduction}

Flaxseed is a good source of oil, protein and fibre. It contains $40-45 \%$ oil, $20-25 \%$ fibre, $20-25 \%$ proteins, and $1 \%$ lignans (Rabetafika et al., 2011). Flaxseed in formulations of some foods is the most important factor for technological properties and health (Bilek and Turhan, 2009, Rabetafika et al., 2011, Mercier et al., 2014). They have a benefical effect on health. Its consumption has been associated with a reduction in the incidence of various types of cancer (Yener, 2011). Human interest in flaxseed has focused on fibres, and on lipids, particularly the essential alpha-linolenic acid (Tarpila et al., 2005).

The functional properties of flaxseed proteins play an important role in the emulsion process (Wang et al., 2010a, Kuhn et al., 2014, Zhao et al., 2015). They affect the water-binding capacity, oil-adsorption capacity, viscosity, gel forming properties of meat products (Wang et al., 2010a, b). They are rich in glutamic acid, arginine and aspartic acid (Chung et al., 2005). Flaxseed proteins are structurally more lipophilic compared to soy proteins. However, the presence of polysaccharide gums in flaxseed-protein preparations are affected by their hydrophilic properties (Oomah and Mazza, 1993). The gum in flaxseed can affects the viscosity and waterbinding, foaming and emulsifying properties of flaxseed protein products (Oomah and Mazza, 1993, Chen, 2007). Generally, protein acts as a main emulsifier, and polysaccharides improve the stability of emulsions by thickening and steric stabilizing properties (Wang et al., 2011). Their interaction can also improve emulsion stability (Wang et al., 2011, Zhao et al., 2015). Flaxseed contains soluble and insoluble fibres. Soluble fibre presents in flaxseed in a mucilage form (8\% dry weight of flaxseed), which is composed of sugars, gums and pectins. Main components of insoluble fibre in flaxseed are lignin, cellulose and hemicellulose (Rubilar, et al., 2010).

The technological properties of flaxseed components can be predicted by the model system. Flaxseed influences on emulsified meat products have been investigated so far by only a few researchers, so there is some information available. The objective of this investigation was to determine the effects of ground flaxseed with $\mathrm{pH}$ on the emulsion properties of beef. 


\section{Materials and Methods}

Beef (Semimembranosus muscle) was used as meat source. Beef and sunflower oil were obtained from local markets. Ground flaxseed (protein $25.1 \%$, fat $24.5 \%$, carbohydrate $35.8 \%$ ) was obtained from Aksu Vital Doğal Ürünler Gıd.San. ve Tic. A.Ş (Istanbul, Turkey).

\section{Meat Homogenate Preparation}

The meat was ground by a grinder (Tefal, LeHachoir 1500, France) using a $3 \mathrm{~mm}$ diameter hole plate. Meat samples were divided into equal lots and packaged by using two layers of polyethylene and this was stored as $22^{\circ} \mathrm{C}$ until it was used.

Homogenate was prepared as; $0.45 \mathrm{M} \mathrm{NaCl}$ solution standardised to a $\mathrm{pH}$ of $6.5 .100 \mathrm{ml}$ of $\mathrm{NaCl}$ solution $\left(4^{\circ} \mathrm{C}\right), 25 \mathrm{~g}$ ground meat and flaxseed were placed into a blender (Waring-80011S, USA) and chopped for $60 \mathrm{sec}$ at $18.000 \mathrm{rpm}$. Then prepared this homogenate were adjusted to $\mathrm{pH}$ using either $0.4-1 \mathrm{~N} \mathrm{HCl}$ or $0.4-1 \mathrm{~N}$ $\mathrm{NaOH}$. The $\mathrm{pH}$ of the $\mathrm{NaCl}$ solution and the homogenate was measured with a $\mathrm{pH}$ meter (Hanna 2215, USA).

\section{Emulsion Capacity (EC)}

Emulsion capacity is the maximum amount of oil emulsified by a protein unit. It was determined using a model system as described by Ockerman (1985) and Zorba et al. (1993). The end point of the oil addition was determined using the electrical conductivity method (Webb et al., 1970). $12.5 \mathrm{ml}$ meat homogenate, $37.5 \mathrm{ml}$ of $0.45 \mathrm{M} \mathrm{NaCl}$ solution and $50 \mathrm{ml}$ of sunflower oil were placed into the blender (Kenwood KM 010, UK) jar at first. At $6500 \mathrm{rpm}$, the oil was added at $0.5-0.6 \mathrm{ml} / \mathrm{sec}$ until the emulsion broke. The water was circulated around the burette containing oil to keep the oil at a constant temperature $\left(20^{\circ} \mathrm{C}\right)$. The electrical conductivity of the emulsion during the emulsification was monitored by a microprocessor. As soon as the conductivity dropped, the addition of oil was stopped immediately. The total of the added oil before and after emulsification was recorded as EC.

\section{Preparation of Meat Emulsion}

$32.5 \mathrm{ml}$ of meat homogenate, $97.5 \mathrm{ml} 0.45 \mathrm{M} \mathrm{NaCl}$ solution and $75 \mathrm{ml}$ of sunflower oil were placed in the blender (Kenwood KM 010, UK) jar. At 6500 rpm, 100 $\mathrm{ml}$ oil was added at a rate of $0.5-0.6 \mathrm{ml} / \mathrm{sec}$. After the oil had been added, the emulsion was stirred for an additional $5 \mathrm{sec}$.

\section{Emulsion Stability (ES)}

ES was determined using a model system, as outlined by Ockerman (1985). $10 \mathrm{~g}$ of emulsion was weighed in the tube and heated at $80^{\circ} \mathrm{C}$ in a water bath for $30 \mathrm{~min}$. Then, the emulsion were cooled to about $25^{\circ} \mathrm{C}$ in a cold water bath. The emulsion was then held for 1 hour at ambient conditions to stabilize and then subjected to centrifugation at $350 \times \mathrm{g}$ for 20 minutes. Water and oil separated from the emulsion were measured and ES was calculated using the following equations:

$\mathrm{ES}(\%)=100-(\mathrm{SW}+\mathrm{SO})$

$\mathrm{SW}(\%)=\mathrm{ml}$ of separated water $\times 10$

SO $(\%)=$ ml of oil separated $\times d \times 10(d$ :specificgravity $)$

\section{Emulsion Density (ED)}

ED is an important feature in fat-containing samples and the method of measurement is one of the simplest methods. It is an analysis that can be done with inexpensive equipment that can be found in many laboratories (Mcclements 1999). The $20 \mathrm{ml}$ emulsion was taken up in a pipette with an enlarged mouth and weighed. ED was calculated as the weight of $20 \mathrm{ml}$ emulsion.

\section{Emulsifying Activity (EA)}

EA was determined using the method described by Neto et al. (2001). $10 \mathrm{~g}$ of emulsion was weighed in a tube and centrifuged. After centrifuging at $350 \mathrm{~g}$ for 20 minutes, the height of the emulsified layer and the height of the total content in the tube were measured. EA was calculated as:

$$
\mathrm{EA}=\frac{(\text { Height of emulsified layer in the tube }) \times 100}{\text { Height of the total contents in the tube }}
$$

\section{Emulsion Viscosity (EV)}

EV was measured with a rheometer (BrookfieldDV3T). RV-3 type a spindle (viscosity range $=100$ $200.000 \mathrm{mPa} . \mathrm{s}$ ) was used to measure emulsion viscosity. The spindle was set to rotate at $15 \mathrm{rpm}$. The rheometer was confirmed by a calibration fluid (Brookfield $4700 \mathrm{cp}$ at $25^{\circ} \mathrm{C}$ ). Prior to the measurement, each sample was standardized for at least 3 hours to allow reaching the required temperature $\left(25^{\circ} \mathrm{C}\right)$.

\section{Experimental Design and Statistical Analysis}

This study was carried out in two replications. The experiments were designed according to the central composite rotatable design. A quadratic model was used to determine the combined effect of two independent variables (flaxseed and $\mathrm{pH}$ ). 10 combinations including two replicates (centre points) were designed in random order. Actual and encoded levels are given in Table 1. The variables were encoded according to the following equation:

$$
\mathrm{X}_{\mathrm{i}}=\left(\chi_{\mathrm{i}}-\bar{\chi}_{\mathrm{i}}\right) / \Delta \chi_{\mathrm{i}}
$$

Where $X_{\mathrm{I}}$ is the encoded value of an independent variable, $\chi_{i}$ is the real value of an independent variable, $\bar{\chi}_{i}$ is the real value of an independent variable at the centre point, $\Delta \chi_{i}$ is the step change.

Table 1 Central composite rotatable design of two independent variables

\begin{tabular}{c|rrrc}
\hline \multirow{2}{*}{$\begin{array}{c}\text { Run } \\
\text { order }\end{array}$} & \multicolumn{2}{|c}{ Codified levels } & \multicolumn{2}{c}{ Actual levels } \\
\cline { 2 - 5 } & $\mathrm{pH}\left(\mathrm{X}_{1}\right)$ & Flaxseed $\left(\mathrm{X}_{2}\right)$ & $\mathrm{pH}$ & Flaxseed(\%) \\
\hline 1 & -1.41 & 0 & 3.88 & 0.25 \\
2 & -1 & -1 & 4.50 & 0.07 \\
3 & -1 & 1 & 4.50 & 0.43 \\
4 & 0 & -1.41 & 6.00 & 0.00 \\
5 & 0 & 0 & 6.00 & 0.25 \\
6 & 0 & 0 & 6.00 & 0.25 \\
7 & 0 & 1.41 & 6.00 & 0.50 \\
8 & 1 & -1 & 7.50 & 0.07 \\
9 & 1 & 1 & 7.50 & 0.43 \\
10 & 1.41 & 0 & 8.12 & 0.25 \\
\hline
\end{tabular}


For each factor evaluated, the variance was divided into linear, quadratic, and interacting components and represented using a second order polynomial equation. The equation is

$$
Y=\beta_{0}+\sum_{i=1}^{k} \beta_{i} x_{i}+\sum_{i=1}^{k} \beta_{i i} x_{i i}^{2}+\sum_{\substack{i=1 \\ i<j}}^{k} \sum_{j=1}^{k} \beta_{i j} x_{i} x_{j}
$$

Where $\mathrm{Y}$ is the estimated response, $k$ is the number of factor variables, $\beta_{0}, \beta_{\mathrm{i}}, \beta_{\mathrm{ii}}, \beta_{\mathrm{ij}}$ are constant coefficients. $X_{i}$, $X_{j}$, are defined as the independent variables. Actual levels were used in the analysis.

\section{Results and Discussion}

The results of analysis of variance indicating the emulsion capacity are presented in Table 2 . The quadratic effects of $\mathrm{pH}$ and the interaction effects between $\mathrm{pH}$ and flaxseed on EC were found to be significant $(\mathrm{P}<0.01)$. The predicted critical value of EC was outside of data range (flaxseed: $0.56 \%, \mathrm{pH}: 7.64)$. As shown in Fig. 1 and 2, EC increased with increasing $\mathrm{pH}$ and flaxseed. In particular, increased EC rate was reduced with alkaline $\mathrm{pH}$ and high levels of flaxseed. $\mathrm{pH}$ plays a significant role during emulsification and is closely related to the physico-chemical and functional properties of the emulsion (Schut, 1976). Kaushik et al. (2015) reported that the isoelectric point $(\mathrm{pI})$ of flaxseed protein isolate was 4.2. In the case of $\mathrm{pH}$ shift from isoelectric point, the solubility of proteins increases (Schut, 1976). Moreover, hydrophilic and lipophilic properties and the balance between them played a significant role in EC values. These properties of the proteins and polysaccharides reduce the interface tension between oil and water and allow emulsion formation with much lower energy input (Elizalde et al., 1988, Krause et al., 2002). Oomah and Mazza (1993) stated that major flaxseed proteins are more lipophilic than soy proteins due to the effect of the polysaccharide composition. Krause et al. The quadratic effects of $\mathrm{pH}$ and also the interaction effects of $\mathrm{pH}$ and flaxseed on EA were found to be significant $(\mathrm{P}<0.01)$. Increase in $\mathrm{pH}$ and flaxseed increased EA values (Fig. 1, 5). Increased EC rate was reduced with high levels of flaxseed. The highest EA value $(71.63 \%)$ in the data range was reached at $0.5 \%$ flaxseed level and at $\mathrm{pH} 8.12$.
The hydration and swelling properties of flaxseed and the size of oil globules might be affected by the emulsion volume. Flaxseed contains a considerable amount of fibres, which might affect emulsion volume (Rubilar et al., 2010). The emulsion activity is related to $\mathrm{pH}$ values (Neto et al., 2001), which affect the solubility of protein and polysaccharide, resulting in differences in net electric charge. Wang et al. (2010a) reported that the droplet size decreases when the flaxeed protein concentration increases from 0.25 to 1.25 .

The linear and quadratic effects of $\mathrm{pH}$ and flaxseed on ES were found to be significant (Table 2). Flaxseed addition increased emulsion stability and the increasing rate was higher in the acidic $\mathrm{pH}$ range than the alkaline $\mathrm{pH}$ range (Fig. 1, 3). The ES values increased with increasing $\mathrm{pH}$ and flaxseed until a critical point, which was reached at a flaxseed level of $0.42 \%$ and a $\mathrm{pH}$ of 7.02. As shown in Fig. 3, the predicted value at solution was a maximum. These findings of ES might be related to protein and polysaccharide contents of flaxseed. Ayad (2010) reported that flaxseed protein products containing high polysaccharide increased the emulsion stability of canned fish sauce. Changes in $\mathrm{pH}$ strongly affect interactions between polysaccharides and proteins in the interface (Khalloufi et al., 2009). When the $\mathrm{pH}$ approaches the $\mathrm{pI}$, the net electric charge approaches zero. The reduction in net electric charge at the droplet surface results in emulsion destabilization (Laplante et al., 2006). Protein / polysaccharide ratio has significant effects on emulsion stability (Kurt 2010). High ratios of protein / polysaccharide mixture usually produce insoluble complexes with poor emulsifying or stabilizing properties, mainly resulting in a charge neutralizing flocculation effect (Laplante et al., 2006). Kaushik et al. (2016) reported that the maximum negative charge in the protein concentrate of flaxseed was found to be $\mathrm{pH} 8.0$ due to the exposure of the anionic groups to the protein surface. In addition, they reported that oil and water absorption and emulsion stability of flaxseed protein concentrate was higher than soybean fiber proteins (Kaushik et al., 2016). Wang et al. (2010a) stated that higher flaxseed concentrations at acid $\mathrm{pH}$ favours quick stabilization of oil interface. This reduces the recoalescence of oil droplets formed during the homogenization, which contributes to emulsion stability.

Table 2 Analysis of variance of the linear, quadratic and interaction effects of $\mathrm{pH}$ and flaxseed on emulsion properties of beef

\begin{tabular}{|c|c|c|c|c|c|c|c|c|c|c|c|}
\hline \multirow[b]{2}{*}{$\begin{array}{l}\text { Source of } \\
\text { variation }\end{array}$} & \multirow[b]{2}{*}{ DF } & \multicolumn{2}{|c|}{$\mathrm{EC}$} & \multicolumn{2}{|l|}{ ES } & \multicolumn{2}{|l|}{ ED } & \multicolumn{2}{|c|}{ EA } & \multicolumn{2}{|l|}{ EV } \\
\hline & & $\begin{array}{l}\mathrm{R}^{2}=0 \\
\mathrm{~F}-\mathrm{va}\end{array}$ & & $\begin{array}{r}\mathrm{R}^{2}=0 \\
\mathrm{~F}-\mathrm{val}\end{array}$ & & $\begin{array}{r}\mathrm{R}^{2}=0 \\
\mathrm{~F}-\mathrm{val}\end{array}$ & & $\begin{array}{r}\mathrm{R}^{2}=0 \\
\mathrm{~F}-\mathrm{val}\end{array}$ & & $\begin{array}{c}\mathrm{R}^{2}=0.9 \\
\text { F-value }\end{array}$ & \\
\hline Model & 5 & 190.058 & ** & 32.322 & $* *$ & 29.269 & $* *$ & 22.806 & $* *$ & 134.088 & *** \\
\hline $\mathrm{X}_{1}$ (Flaxseed) & 1 & 0.523 & & 7.736 & $*$ & 0.017 & & 4.260 & & 4.719 & * \\
\hline $\mathrm{X}_{2}(\mathrm{pH})$ & 1 & 0.196 & & 16.883 & $* *$ & 5.103 & $*$ & 32.125 & ** & 6.256 & * \\
\hline $\mathrm{X}_{1} * \mathrm{X}_{2}$ & 1 & 17.974 & $* *$ & 2.736 & & 1.319 & & 27.529 & ** & 4.116 & \\
\hline $\mathrm{X}_{1} * \mathrm{X}_{1}$ & 1 & 0.007 & & 8.947 & $* *$ & 0.0002 & & 3.961 & & 4.311 & \\
\hline $\mathrm{X}_{2} * \mathrm{X}_{2}$ & 1 & 42.107 & $* *$ & 39.818 & $* *$ & 0.044 & & 0.037 & & 50.272 & ** \\
\hline Lack of fit & 9 & 3.468 & & 0.663 & & 0.634 & & 0.304 & & 0.988 & \\
\hline Error & 14 & & & & & & & & & & \\
\hline C. Total & 19 & & & & & & & & & & \\
\hline
\end{tabular}


Table 3 Predicted model equations for effects of $\mathrm{pH}\left(\mathrm{X}_{1}\right)$ and flaxseed $\left(\mathrm{X}_{2}\right)$ on emulsion properties of beef

$\mathrm{Y}_{\mathrm{EC}}=135.555+70.821 \mathrm{x}_{1}+0.936 \mathrm{x}_{2}-10.486 \mathrm{x}_{1} \mathrm{x}_{2}+4.754 \mathrm{x}_{1}{ }^{2}-0.590 \mathrm{x}_{2}{ }^{2}$
$\mathrm{Y}_{\mathrm{ES}}=39.818-123.439 \mathrm{x}_{1}+3.934 \mathrm{x}_{2}+1.826 \mathrm{x}_{1} \mathrm{x}_{2}-79.313 \mathrm{x}_{1}{ }^{2}-0.260 \mathrm{x}_{2}{ }^{2}$
$\mathrm{Y}_{\mathrm{ED}}=0.8729-0.0395 \mathrm{x}_{1}-0.0148 \mathrm{x}_{2}-0.0087 \mathrm{x}_{1} \mathrm{x}_{2}+0.0023 \mathrm{x}_{1}{ }^{2}-0.0001 \mathrm{x}_{2}{ }^{2}$
$\mathrm{Y}_{\mathrm{EA}}=23.580-89.103 \mathrm{x}_{1}+5.278 \mathrm{x}_{2}+5.635 \mathrm{x}_{1} \mathrm{x}_{2}-51.334 \mathrm{x}_{1}{ }^{2}+0.008 \mathrm{x}_{2}{ }^{2}$
$\mathrm{Y}_{\mathrm{EV}}=8425.144+17601.506 \mathrm{x}_{1}+437.181 \mathrm{x}_{2}+408.976 \mathrm{x}_{1} \mathrm{x}_{2}+10051.406 \mathrm{x}_{1}{ }^{2}+53.320 \mathrm{x}_{2}{ }^{2}$

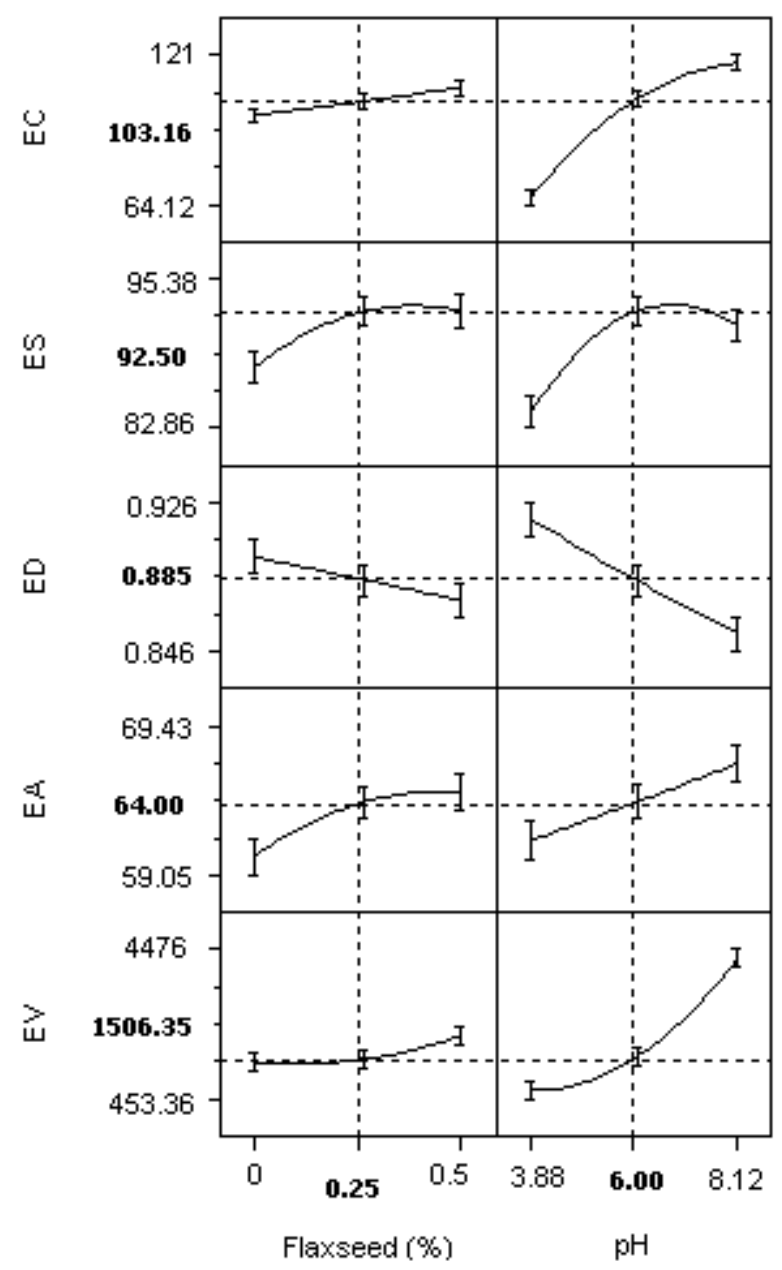

Figure 1 Prediction profilers of effects of $\mathrm{pH}$ and flaxseed on emulsion properties of beef

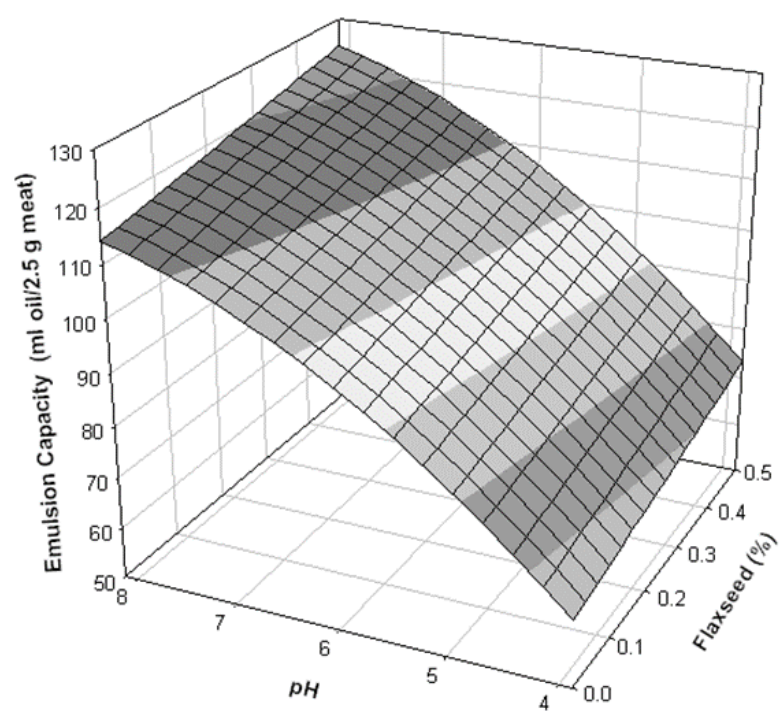

Figure 2 Effects of $\mathrm{pH}$ and flaxseed on EC of beef
The linear effects of $\mathrm{pH}$ on $\mathrm{ED}$ were found to be significant $(\mathrm{P}<0.05$, Table 2$)$. The increase in $\mathrm{pH}$ values reduced the emulsion density (Fig. 1, 4). ED might be affected by the air inclusion and size of oil globules due to the lower density of air and oil. Although flaxseed decreased ED values, this effect was not found to be significant (Table 2).

The linear effects of flaxseed and $\mathrm{pH}$ on $\mathrm{EV}$ were found to be significant $(\mathrm{P}<0.05$, Table 2$)$. As shown in Fig. 1 and $6, \mathrm{pH}$ and high levels of flaxseed increased emulsion viscosity. The solubility of meat proteins and also flaxseed components such as protein and polysaccharides might play a major role in emulsion viscosity. The main soluble fibre fractions of flaxseed were the mucilage gums, and main insoluble fibre fractions were cellulose and lignin. Mucilage consists of polysaccharides, such as pentosans, which become viscous when mixed with water (Ayad, 2010). Pentosans had a considerably effect on the rheological properties of emulsified food products (Ayad, 2010, Krause, 2002). A protein complexation with phytic acid and pentosans had significant effects on emulsifying properties (Krause, 2002). The changes in $\mathrm{pH}$ values might have a significant effect on this complex formation and its behaviour. Khalloufi et al. (2009) reported that the charged proteins can interact with charged polysaccharides on the surface of the emulsion droplets. Also they stated that these interactions can be controlled to increase thickness of the surface layer surrounding the droplets and to form multilayered surfaces.

As shown in Table 2, the quadratic effect of $\mathrm{pH}$ on EV was more significant $(\mathrm{P}<0.01)$ than the linear effect. $\mathrm{pH}$ increased $\mathrm{EV}$, and the increased rate was higher in the alkaline $\mathrm{pH}$ range than in the acidic $\mathrm{pH}$ range (Fig. 1 and 6 ). The solution of the response surface was a minimum, and the predicted value at solution was $687.62 \mathrm{cP}$. The solubility and interactions in proteins / polysaccharides may be controlled by pH (Kurt, 2010). Zhao et al. (2015) reported that the rheological properties of emulsions are related to nature of the protein and polysaccharide and also on their interaction. The rheological properties of protein solutions, particularly viscosity, are a main function of molecular shape, size, degree of hydration, flexibility and intermolecular interactions (Elizalde et al., 1988). Wang et al. (2010b) reported that flaxseed protein concentration decreased droplet size and increased the emulsion's viscosity. Chen et al. (2007) reported that the interaction between salt soluble meat proteins and flaxseed gum affected the rheological properties of their solution.

The effects of $\mathrm{pH}$ and flaxseed and their interaction on emulsion properties were also given mathematically in Table 3. These predicted model equations are beneficial in understanding the effects and interactions of factor levels. 


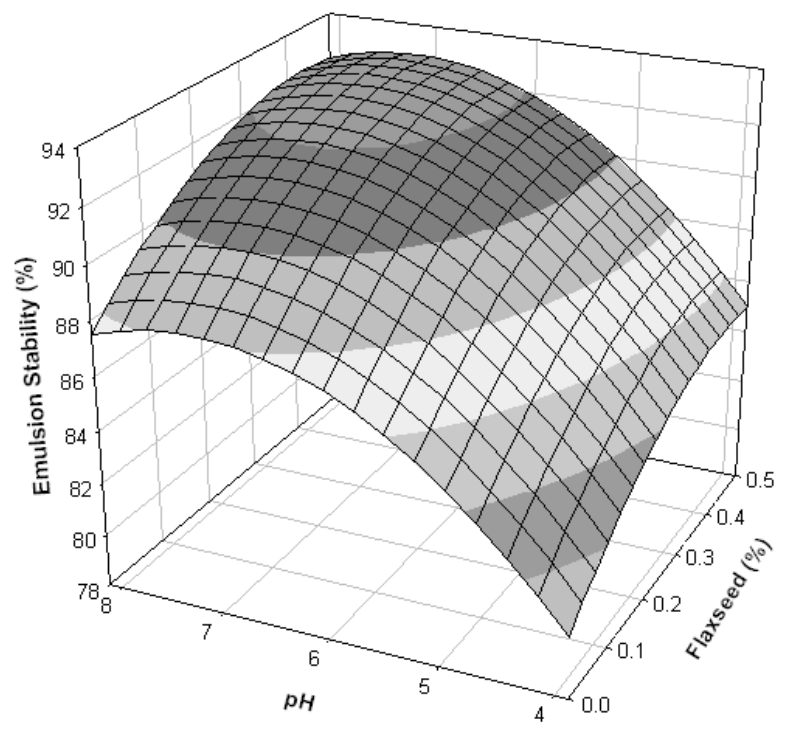

Figure 3 Effects of $\mathrm{pH}$ and flaxseed on emulsion stability of beef

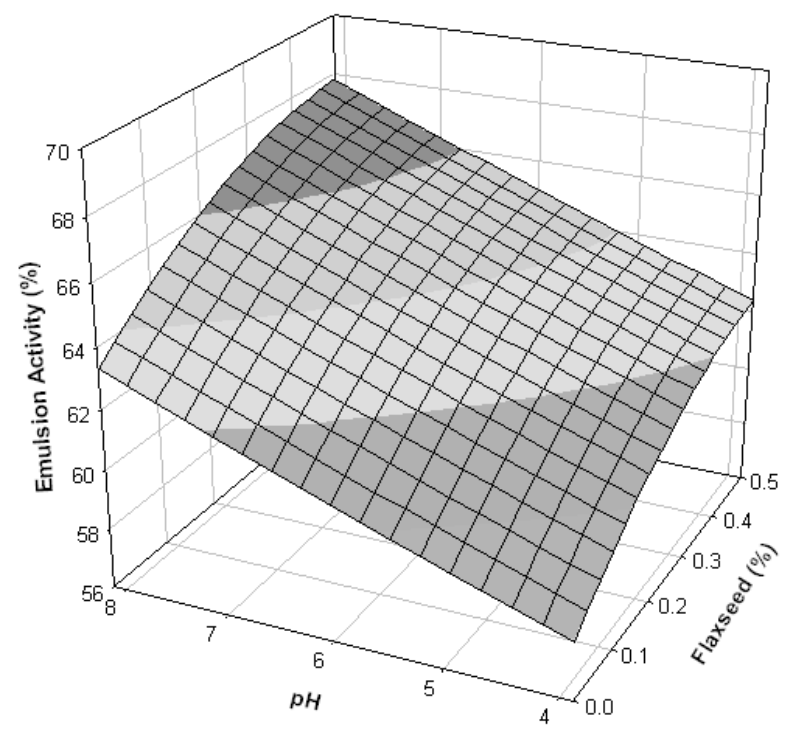

Figure 5 Effects of $\mathrm{pH}$ and flaxseed on emulsion activity of beef

\section{Conclusion}

Flaxseed and $\mathrm{pH}$ improve emulsion properties of beef. In addition, their interaction effects have beneficial effects on emulsion capacity and activity. Their effects on beef emulsion are higher in an acidic medium than in a basic medium with the exception of viscosity. Flaxseed can be used as a functional ingredient in emulsified meat products to improve emulsion properties such as emulsion stability, capacity and rheology.

\section{References}

Ayad AA. 2010. Characterization and properties of flaxseed protein fractions [PhD Thesis]. McGill University, Department of Food Science and Agricultural Chemistry, France.

Bilek E, Turhan S. 2009. Enhancement of the nutritional status of beef patties by adding flaxseed flour. Meat Science. 82: 472477.

Chen HH, Xu SY, Wang Z. 2007. Interaction between flaxseed gum and meat protein. Journal of Food Engineering. 80: 1051-1059.

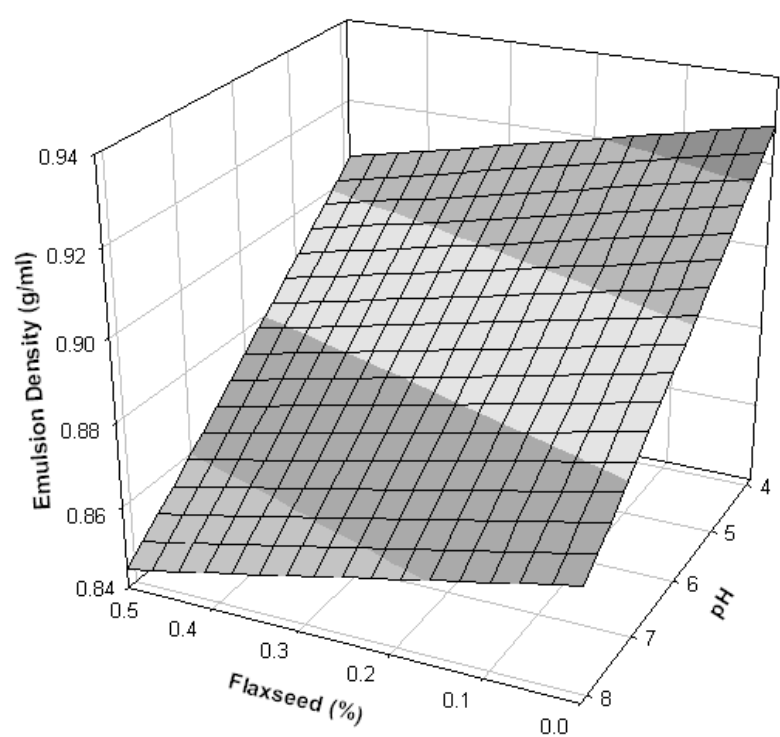

Figure 4 Effects of $\mathrm{pH}$ and flaxseed on emulsion density of beef

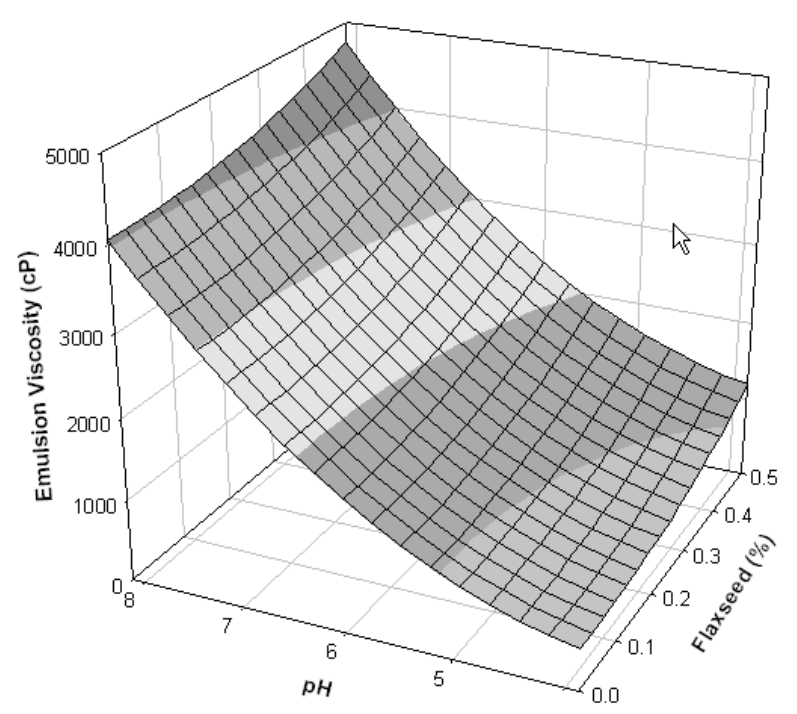

Figure 6 Effects of $\mathrm{pH}$ and flaxseed on emulsion viscosity of beef

Chung M, Lei B, Li-Chan E. 2005. Isolation and structural characterization of the majör protein fraction from NorMan flaxseed (Linum usitatissimum L.). Food Chemistry. 90: 271-279.

Elizalde BE, Kanterewicz RJ, Pilosof AMR, Bartholomai GB. 1988. Physicochemical properties of food proteins related to their ability to stabilize oil-in-water emulsions. Journal of Food Science. 53: 845-848.

Kaushik P, Dowling K, Barrow CJ, Adhikari B. 2015. Complex coacervation between flaxseed protein isolate and flaxseed gum. Food Research International. 72: 91-97.

Kaushik P, Dowling K, McKnight S, Barrow CJ, Wang B, Adhikari B. 2016. Preparation, characterization and functional properties of flax seed protein isolate. Food Chemistry. 197: 212-220.

Khalloufi S, Corredig M, Goff HD, Alexander M. 2009. Flaxseed gums and their adsorption on whey protein-stabilized oil-inwater emulsions. Food Hydrocolloid. 23: 611-618.

Kuhn KR, Silva FGD, Netto FM, Cunha RL. 2014. Assessing the potential of flaxseed protein as an emulsifier combined with whey protein isolate. Food Research International. 59: 89-97.

Krause JP, Schultz M, Dudek S. 2002. Effect of extraction conditions on composition, surface activity and rheological properties of protein isolates from flaxseed (Linum usitativissimum). Journal of the Science of Food Agriculture. 82: 970-976. 
Kurt Ş. 2010. Effects of $\mathrm{pH}$ and Chitosan on Beef Emulsion Properties. International Journal of Food Science Technology. 45: 140-146.

Laplante S, Turgeon SL, Paquin P. 2006. Emulsion-stabilizing properties of chitosan in the presence of whey protein isolate: Effect of the mixture ratio, ionic strength and $\mathrm{pH}$. Carbohydrate Polymers. 65: 479-487.

Mcclements DJ. 1999. Characterization of emulsion properties. In food emulsions: principles and techniques, CRC Press, Boca Raton.

Mercier S, Villeneuve S, Moresoli C, Mondor M, Marcos B, Power KA. 2014. Flaxseed-Enriched Cereal-Based Products: A Review of the Impact of Processing Conditions. Comprehensive Reviews in Food Science and Food Safety. 13: 400-412.

Neto VQ, Narain N, Silva JB, Bora PS. 2001. Functional properties of raw and heat processed cashew nut (Anacardium occidentale, L.) kernel protein isolates. Nahrung. 45: 258-262.

Ockerman HW. 1985. Emulsfying capacity and stability In: Quality control of post mortem muscle tissue. The Ohio State University, Columbus, Ohio.

Oomah BD, Mazza G. 1993. Flaxseed proteins--a review. Food Chemistry. 48: 109-114.

Rabetafika, H. N., V. V. Remoortel, S. Danthine, M. Paquot and C. Blecker. 2011. Flaxseed proteins: food uses and health benefits. International Journal of Food Science Technology. 46: 221-228.

Rubilar M, Gutiérrez C, Verdugo M, Shene C, Sineiro J. 2010 Flaxseed as a source of functional ingredients. Journal of Soil Science and Plant Nutrition. 10: 373-377.

Schut J. 1976. In: Friberg S, editor. Meat emulsions. In: Food Emulsions. Marcel Dekker Inc, New York, US.
Tarpila A, Wennberg T, Tarpila S. 2005. Flaxseed as a functional food. Current Topics in Nutraceutical Research. 3: 167-188.

Wang B, Li D, Wang LJ, Adhikari B, Shi J. 2010a. Ability of flaxseed and soybean protein concentrates to stabilize oil-inwater emulsions. Journal of Food Engineering. 100: 417-426.

Wang B, Li D, Wang LJ, Özkan N. 2010b. Effect of concentrated flaxseed protein on the stability and rheological properties of soybean oil-in-water emulsions. Journal of Food Engineering. 96: 555-561.

Wang B, Wang LJ, Li D, Adhikari B, Shi J. 2011. Effect of gum Arabic on stability of oil-in-water emulsion stabilized by flaxseed and soybean protein. Carbohydrate Polymers. 86: 343351.

Webb NB, Ivey JF, Craig HD, Jones VA, Monroe RJ. 1970. The measurement of emulsifying capacity by electrical resistance. Journal of Food Science. 35: 501.

Yener I. 2011. Keten tohumu ve fitoterapi [MS Thesis]. Ankara, Turkey: University of Gazi, Ankara.

Zhao Q, Long Z, Kong J, Liu T, Sun-Waterhouse D, Zhao M. 2015. Sodium caseinate/flaxseed gum interactions at oil-water interface: Effect on protein adsorption and functions in oil-inwater emulsion. Food Hydrocolloid. 43: 137-145.

Zorba Ö, Gökalp HY, Yetim H, Ockerman HW. 1993. Salt phosphate and oil temperature effects on emulsion capacity of fresh or frozen meat and sheep tail fat. Journal of Food Science. 58: 492-496. 